\title{
The Value-relevance of Disclosed Summarised Financial Information of
}

\section{Listed Associates}

Wessel M. Badenhorst ${ }^{{ }^{*}}{ }^{*}$, Leon M. Brümmer ${ }^{b}$, Johannes H.vH. de Wet ${ }^{b}$

a Department of Accounting, Faculty of Economic and Management Sciences, University of Pretoria, Pretoria, 0002, Republic of South Africa

E-mail: wessel.badenhorst@up.ac.za

Tel: +27 124203421

Fax: +27 123625142

$b \quad$ Department of Financial Management, Faculty of Economic and Management Sciences, University of Pretoria, Pretoria, 0002, Republic of South Africa leon.brummer@inetbfa.com; johannes.dewet@up.ac.za

* Corresponding author

This paper has been published in the Journal of International Accounting, Auditing and Taxation, 2015, vol. 24, pp. 1-12. 


\title{
The Value-relevance of Disclosed Summarised Financial Information of
}

\section{Listed Associates}

\begin{abstract}
Prior research considers limited elements of the summarised financial information disclosed for equity accounted associates under IAS 28. Moreover, prior research does not consider the collective or incremental value-relevance of these disclosures. This study investigates the incremental value-relevance of all the required elements of disclosed summarised financial information for listed associates and controls for disclosed fair values. Findings suggest that individual elements of disclosed summarised financial information are sometimes incrementally valuerelevant, but that the elements have the greatest incremental value-relevance as a group. These findings imply that investors value a firm's investments in listed associates at a self-developed intrinsic value, rather than using the market value (fair value) of that associate directly. By extension, underlying accounting information of listed associates remains value-relevant, even when alternative market-based valuations are available.
\end{abstract}

Keywords: Equity accounting; investments in associates; disclosure 


\section{Introduction}

The objective of financial statements per the Conceptual Framework is to provide information about the reporting entity that is useful to existing and potential investors, lenders and other creditors in making decisions about providing resources to an entity (IASB, 2010: OB2). Decision-useful information can be conveyed in financial statements by recognising an accounting amount in the financial statements or by disclosing the information in the notes. To assess the decision-usefulness of financial statement information, either recognised or disclosed, a value-relevance approach is often utilised. An accounting amount or disclosure is value-relevant if it has a predicted association with equity market values (Barth et al., 2001: 79), i.e. the amount is utilised by equity investors in valuing the firm's equity and is therefore inferred to be decision-useful.

In the case of equity accounted investments in listed associates, an accounting carrying amount as well as several disclosures are reported in financial statements. In this respect, prior research considers the value-relevance of a limited number of these disclosures on an individual basis. For example, Graham, Lefanowicz and Petroni (2003) find that the difference between disclosed fair values and equity accounted carrying amounts of listed associates is value-relevant. Richardson et al. (2012) conclude that liability disclosures of equity accounted joint ventures are value-relevant for a sample of Canadian joint ventures. O'Hanlon and Taylor (2007) find that disclosed liabilities of equity accounted investees in the United Kingdom are value-relevant and that the relationship is stronger for joint ventures than associates. However, as prior research does not consider all of the available disclosures or their collective value-relevance, it remains unclear whether these disclosures are incrementally value-relevant, whether individually or collectively.

This paper contributes to the existing value-relevance literature on investments in associates in several ways. Firstly, this paper focuses explicitly on the incremental value- 
relevance of the disclosed summarised financial information (total assets, total liabilities, revenue and profit or loss of the associates). This information should be incorporated into the fair value (market value) of listed associates, as market participants would take into account all relevant accounting and other information of the associate. Consequently, the disclosed summarised financial information may not be incrementally value-relevant. In contrast to prior research, this study therefore controls for disclosed fair values of listed associates. Secondly, prior research does not consider the value-relevance of all required disclosures. Disclosed summarised financial information still to be investigated includes the total assets, revenue and profit or loss of equity accounted investees. These could represent important omitted correlated variables, as they are incorporated, directly or indirectly, into the calculation of the book value of the investee. By controlling for all required disclosures, this study is able to provide particular insight into the incremental value-relevance of disclosed summarised financial information of equity accounted listed associates.

A third contribution is that this study finds that individual elements of disclosed summarised financial information for listed associates are not consistently value-relevant. Rather, the elements of disclosed summarised financial information have the greatest incremental value-relevance when they are considered collectively. This conclusion is significant, as it implies that investors do not always utilise unadjusted market valuations to which reported fair values equate. Instead, they develop their own valuation of investments in listed associates. By extension, underlying accounting information of listed associates remains value-relevant, even when alternative market-based valuations are available.

A debate about the appropriateness of equity accounting is still ongoing and some have called for it to be replaced with fair value accounting (Nobes, 2002). In this context, the findings of this study provides useful insight into what information equity investors use to value investments in equity accounted listed associates. The findings of this study are 
therefore of interest to those involved in the fair value accounting debate. Furthermore, the findings suggest that equity investors, on average, develop intrinsic values for investments in associates, rather than using their market (i.e. fair) values directly. This is of interest in a valuation research context, especially as many valuation texts advocate incorporating the unadjusted fair value of an associate in the valuation of the investor (Koller, Goedhart, \& Wessels, 2010; Nissim \& Penman, 2001).

The remainder of this paper is set out as follows: section two briefly discusses the current accounting and disclosure requirements for investments in associates, followed by a review of prior literature. Sections four to six set out the research methodology, the sampling methodology and the descriptive statistics. The results of univariate investigations are discussed in section seven, followed by those of the multivariate investigations in section eight and results from robustness tests in section nine. Section ten summarises the contribution and implications of the paper, followed by a concluding section.

\section{Current accounting and disclosure requirements for investments in associates}

The accounting and disclosure requirements for investments in associates for the sample period are set out in IAS 28, Investments in Associates, effective January 2005 (hereafter: IAS 28) (IASB, 2003), which requires most entities to equity account their investments in associates $^{1}$. An associate is an investee over which the entity has significant influence, which is the power to participate in financial and operating decisions. Significant influence usually, but not necessarily, exists when an entity holds twenty per cent or more of the voting power of an investee.

Equity accounting requires an entity to recognise the investment at its cost and adjust it for the net impact of subsequent changes in equity. Unlike consolidation, this is not a line-

1 This version of IAS 28 has since been superseded. However, the relevant requirements of IAS 28, Investments in Associates and Joint Ventures, effective January 2013 (IASB 2011), are identical to those discussed in this section. 
by-line process and equity accounting results in a single line item (investment in associate) on the statement of financial position. Similarly, a single line item is reported relating to the investment in associate in profit or loss and a single line item is included for the investor's share of the associate's other comprehensive income. In addition, IAS 28 also contains disclosure requirements. Firstly, entities are required to disclose the fair values of investments in associates for which published price quotations are available. Secondly, entities are required to disclose summarised financial information of their associates, which must include their total liabilities, total assets, revenue and profit or loss.

The next section provides an overview of the current state of the literature.

\section{Literature review}

Early value-relevance research for investments in associates considered the value-relevance of their carrying amounts and disclosed fair values. Barth and Clinch (1998) investigate investments in associates for an Australian sample from 1991 to 1995 and find that disclosed fair values were only value-relevant for mining firms. In addition, Barth and Clinch (1998) conclude that the carrying amounts of investments in associates were only value-relevant for financial and mining firms. However, as Australia only adopted equity accounting from 1998 onwards (Nobes, 2002) these carrying amounts were the cost of the associates. Graham, Lefanowicz and Petroni (2003) consider equity accounted carrying amounts of listed associates and find that the equity accounted carrying amounts as well as the difference between their disclosed fair values and equity accounted carrying amounts are value-relevant. Importantly, Graham, Lefanowicz and Petroni (2003) exclude only financial services firms from their sample, which suggests that disclosed fair values are value-relevant for diverse industries.

Liability disclosures relating to equity accounted investees have also been investigated by prior researchers, as such liabilities may represent hidden liabilities of the 
reporting entity (Baumann, 2003; O’Hanlon and Taylor, 2007). Baumann (2003) finds, for example, that investor-guaranteed obligations of equity accounted investments are negatively associated with the investor's market value, but does not distinguish between joint ventures and associates. Richardson et al. (2012) confirm that liability disclosures of equity accounted joint ventures are value-relevant for a sample of Canadian joint ventures. O'Hanlon and Taylor (2007) is the first study to investigate disclosed liabilities of equity accounted associates separately. They find that disclosed liabilities are negatively associated with the market value of equity of the reporting entity for equity accounted joint ventures and associates in the United Kingdom, but that the relationship is stronger for joint ventures.

However, research on disclosed liabilities does not control for other information disclosed about the equity accounted investees and therefore ignores the fact that the investee may be able to settle its liabilities comfortably. If this is the case, the investee's liabilities may no longer affect the market value of equity of the reporting entity significantly. For this reason, investors need additional information about the financial strength of the investee. This information potentially includes the total assets, revenue and profit or loss disclosures for equity accounted associates. However, prior research does not investigate these disclosures directly. Soonawalla (2006) offers some indirect evidence that disaggregating equity accounted carrying amounts and income of associates and joint ventures improves the information content of both equity accounted carrying amounts and equity accounted income. This suggests that aggregation conceals valuable information and offers some preliminary evidence that investors use information about the profit or loss of an associate, however, the incremental value-relevance of the disclosure is still in doubt.

In summary, prior research finds that disclosed fair values of listed associates and the disclosed total liabilities of associates are value-relevant. However, prior research considers these items in isolation, does not directly consider the other items of disclosed summarised 
financial information and does not control for disclosed fair values. Controlling for disclosed fair values in this context is important, as the fair values may subsume a large portion of the information content of disclosed summarised financial information ${ }^{2}$. The hypothesis for this study (in null form) is therefore that disclosed summarised financial information of listed associates (i.e. disclosed revenue, profit or loss, total assets and total liabilities) is not valuerelevant.

\section{Research methodology}

The hypothesis of this study considers the value-relevance of the disclosed summarised financial information of associates. Importantly, in contrast to prior research, the model controls for information content captured by disclosed fair values and is specified as follows:

$$
\begin{aligned}
& M V_{E}=\alpha_{0}+\alpha_{1} \Sigma \text { Year }+\alpha_{2} \Sigma C T R Y+\beta_{1} B V_{E x c l}+\beta_{2} A S C_{C A} \\
& +\beta_{3} A S C_{F V}+\beta_{4} D I S C L+\beta_{5} N I+\beta_{6} N e g+\varepsilon
\end{aligned}
$$

Where:

$M V_{E} \quad$ represents the market value of equity three months after reporting date;

Year represents an indicator variable, set to one if an observation falls into a given sample year and zero otherwise;

CTRY represents an indicator variable, set to one if an observation falls into a given sample country and zero otherwise;

$B V_{E x c l} \quad$ represents the book value of equity, excluding the equity accounted carrying amount of listed associates, at the reporting date;

NI represents net income from continuing operations attributable to ordinary shareholders of the reporting entity for the reporting period;

2 As accounting standards do not require fair values to be disclosed for joint ventures or unlisted associates, prior research focused on such investees could not control for disclosed fair values. 
Neg is an indicator variable, set to one if net income from continuing operations attributable to ordinary shareholders is negative and zero otherwise;

$A S C_{C A} \quad$ represents the equity accounted carrying amount of the listed associate;

$A S C_{F V} \quad$ represents the disclosed fair value of the listed associate; and

DISCL represents one element of the summarised financial information being assessed for value-relevance. As such DISCL alternatively represents the total revenue, total profit or loss, total assets or total liabilities of the associate. In a final specification, DISCL is subdivided to include all of the different items of disclosed summarised financial statement information of the associate.

All variables, except Year and CTRY are scaled by number of shares outstanding, as Barth and Clinch (2009) show that this most reliably compensates for incorrect inferences as a result of scale effects. Time and firm subscripts are suppressed.

The variable of interest in the various specifications is $D I S C L$, where significance indicates whether or not an item of disclosed summarised financial information is value-relevant. However, this does not indicate whether or not disclosed fair values of the listed associates subsume the summarised financial information disclosed.

In order to investigate this, the error term $(\varepsilon)$ is important, as $\mathrm{Gu}(2007)$ shows that comparisons of $\mathrm{R}^{2} \mathrm{~s}$ are generally inappropriate. Therefore the Vuong-test (Vuong, 1989) is used to assess the incremental value-relevance of non-nested models, which is based on the unstandardized residuals from the structural portion of a maximum likelihood autoregression in this study. The Vuong-test focuses on the variance in the error terms $(\mathrm{Gu}, 2007)$ and is often utilised in value-relevance research when alternative accounting specifications are considered (Dechow, 1994; Ashbough \& Olsson, 2002; Pouraghajan et al., 2012). Note that the Vuong-test is directional. If the test statistic is significantly positive, the first model is 
superior to the second model and, conversely, if the test statistic is significantly negative, the second model is superior to the first model.

In addition to the Vuong-test, the Dispersion-test is performed, which simply compares the variance of the unstandardized residuals of differing models using a paired sample ANOVA. Although the test is simplistic compared to the Vuong-test, the results of the Dispersion-test are easy to understand and tend to be qualitatively similar to those of the Vuong-test ${ }^{3}$. Importantly, however, both of these tests are appropriate for the comparison of model specifications as they ignore the impact of dispersion in the independent variables, which is the reason that $R^{2}$ s should not be compared across models (Gu, 2007).

More specifically, incremental value-relevance is investigated by specifying a base model, which is model (1) with DISCL omitted. Thereafter, the variance in $\varepsilon$ when model (1) includes each specification of DISCL is compared with the variance in $\varepsilon$ in the base model. A significant reduction of the variance in $\varepsilon$ indicates a significant reduction in measurement error, i.e. an increase in relevance and faithful representation from that of the base model. This would imply that the summarised financial statement information is not wholly captured by disclosed fair values of associates. However, because this may merely reflect that all the summarised financial statement information is necessary for investors to determine an intrinsic value for the investment in the associate, a specification where all the disclosed summarised financial information is included in the model is also performed. A reduction in the variance of $\varepsilon$ compared to any of the previous specifications, including the base model, would indicate that the disclosed summarised financial information provides incremental information to that included in the previous specification. In other words, this would imply that investors utilise the summarised financial information of the associate to determine an

3 The Dispersion-test is simplistic in nature as it does not compensate for the mechanical impact of increasing the number of independent variables on the error term. Due to the fact that it is easy to understand and the models differ by a small number of independent variables, it has been reported. However, this test could be inappropriate where competing models differ by a large number of independent variables. 
intrinsic value for the firm's investment that is not equal to the disclosed fair value or equity accounted carrying amount.

Based on prior research, which found a negative relationship between disclosed total liabilities of equity accounted investees and the market value of the firm (O'Hanlon \& Taylor, 2007, Richardson et al., 2012), it is predicted that the coefficient on DISCL will be negative when specified as total disclosed liabilities of the associate. As prior research has not investigated other the summarised financial information disclosures, no prediction is made regarding the sign of these coefficients.

\section{Sampling methodology, data and final sample numbers}

The sample is selected using the 250 largest firms listed on each of the main boards of the Johannesburg Stock Exchange (JSE) in South Africa, the Australian Securities Exchange (ASX) in Australia and the London Stock Exchange (LSE) in the United Kingdom, based on market capitalisation determined as at 31 December 2011. Selection of these sample countries ensures consistent accounting standards [International Financial Reporting Standards (IFRS)] and similar legal, professional and regulatory frameworks, due to a shared colonial heritage. This mitigates cross-country differences, which are affected by the common or code law characteristics of a country (Ball et al., 2003). The final sample includes only annual firm-years with investments in listed associates for the period 31 December 2005 to 31 December 2011, as the version of IAS 28 utilised in this study became effective on 1 January 2005, the same year in which the sample countries adopted IFRS. The initial sample includes firms from all industries, although subsequent robustness tests exclude financial, mining and utility firms. Robustness tests to assess the impact of excluding loss firms from the sample are also performed.

Price data and financial statement data are obtained from Datastream and converted to South African Rands (ZAR) for comparative purposes. Required data items not available on 
the database, including disclosed fair values and disclosed summarised financial information, are hand-collected from published financial statements. Should a sample firm omit these disclosures or fail to disclose the information separately for listed and unlisted associates, the fair value of its stake and summarised financial information are obtained from publically available information. It is not possible to independently recalculate all disclosed fair values, as sample firms do not always disclose the exact interest held in their associates.

Furthermore, the interest held cannot be verified with reference to the associate's financial statements when reporting dates differ. In the interest of comparability, disclosed fair values are used as far as possible and reliance is placed on the fact that all financial statements in the sample were audited. Should it be necessary to collect summarised financial information from sources outside the sample firm's financial statements, it is obtained from the latest annual report of the associate of the same or earlier date than that of the investor's annual report to ensure that investors would have had access to the information utilised in this study.

Some of the initial firm-years are lost where sample firms were not listed for the whole of the year. In addition, a large number of firms provide inadequate disclosure about investments in associates in their financial statements and are excluded from the final sample, if this information could not be rectified with reference to other publically available information. An example of such inadequate disclosure is where the equity accounted carrying amounts of associates and joint ventures are not distinguished. A reconciliation of sample firm-years is provided in Table 1.

\section{[INSERT TABLE 1 ABOUT HERE]}

\section{Descriptive statistics}

Descriptive statistics for unscaled variables are detailed in Panel A of Table 2. Amounts have been converted to South African Rand (ZAR) for comparative purposes. From the table it 
appears that sample firms are fairly large with a mean (median) market value of equity of ZAR 155311 million (ZAR 39987 million). This is partly due to the nature of the study; only large firms have sufficient means to invest in associates large enough to be listed themselves. This is borne out by the composition of the final sample, where more than 90 per cent of final sample firms are within the top 150 firms listed on the relevant exchange. By comparison the mean (median) book value of equity, which excludes the equity accounted carrying amounts of listed associates for the purposes of this study, is ZAR 66986 million (ZAR 21928 million). The difference between the mean and median of book value of equity implies some skew in the sample, which is also present in net income from continuing operations, which has a mean value of ZAR 10100 million compared to a median of ZAR 2485 million.

\section{[INSERT TABLE 2 ABOUT HERE]}

When the variables specific to investments in associates are considered, it is worth noting that mean (median) disclosed fair values of ZAR 13645 million (ZAR 1017 million) are 124 per cent (17 per cent) higher than the mean (median) equity accounted carrying amounts. The variables relating to the disclosed summarised financial information of listed associates suggest, not unexpectedly, that associates are generally smaller than their investors. For example, mean (median) disclosed net profit of listed associates is ZAR 3604 million (ZAR 132 million), which is markedly smaller than the net income from continuing operations of the sample firms. The skew evident when the means and medians of the disclosed total assets and total liabilities of listed associates are compared is due to the inclusion of financial services firms in the sample. As associates generally tend to operate in 
the same industry as their investors, total assets and liabilities of the associates of financial services firms tend to be much higher than those of firms operating in other industries.

Indeed, when financial services firms are excluded from the sample, skew reduces for the disclosed summarised financial information of listed associates as well as other scale variables. Untabulated results show that differences between mean and median values decrease for book value of equity, disclosed total assets, total liabilities, profit or loss, and revenue of the listed associates. However, the difference between the mean (median) equity accounted carrying amounts and mean (median) disclosed fair values of listed associates remains relatively unchanged at 154 per cent ( 25 per cent).

The potential impact of the sample distribution on results of analyses is dealt with in several ways. Skew is reduced primarily by using scaled variables. Panel B of Table 2 reveals that scaling by number of shares outstanding markedly reduces the observed skew in variables. In addition, autoregression with maximum likelihood estimation is used (a robust regression method). Lastly, five outlying observations (tails) with residuals more than 2.5 standard deviations from the mean are identified in an initial regression and deleted. The impact of financial services firms and loss firms on inferences is considered with reference to a robustness test where these firm-years are excluded from the sample.

In the sections which follow, the detailed findings from univariate and multivariate analyses of the sample firm-years are discussed.

\section{Univariate investigations}

The results of univariate investigations are tabulated in Table 3 with Pearson (Spearman) correlations above (below) the diagonal. Most of the independent variables have significant positive correlations with the dependent variable (market value of equity, three months after reporting date) at the one per cent level. The exceptions are the equity accounted carrying amounts of listed associates and their disclosed summarised financial information. Equity 
accounted carrying amounts have a positive Pearson correlation with market value of equity, which is significant at the ten per cent level $(p=0.051)$. Disclosed net profit of listed associates and their disclosed revenue also have positive correlations with market value of equity, but at the five per cent level of significance.

The remaining disclosed summarised financial information, namely disclosed total assets and total liabilities of listed associates, have insignificant Pearson correlations with market value of equity. Oddly, in the case of disclosed total assets, the correlation is negative, although insignificant $(\mathrm{p}=0.816)$. However, a large number of the independent variables are significantly correlated with each other at the one per cent level. The disclosed total assets and disclosed total liabilities of associates have an especially high Pearson correlation (0.978) at the one per cent level of significance $(\mathrm{p}<0.001)$. This is not unsurprising as these variables comprise the components of book value of equity and the ability to incur liabilities is often determined with reference to a firm's assets. Importantly, this correlation suggests that the negative sign of disclosed total assets could be due to the correlation with disclosed total liabilities.

The fact that not all summarised disclosed financial information exhibit significant correlations with market value of equity offers an initial suggestion that not all of these are individually value-relevant. However, this study relies on the results of the multivariate investigations. These are discussed in the section which follows.

\section{[INSERT TABLE 3 ABOUT HERE]}

\section{Detailed multivariate regression findings}

The main regression results are detailed in Table 4. The first model in this table represents the base model, in which no disclosed summarised financial information of listed associates has been included. In each of the successive models, one item of disclosed summarised financial 
information is introduced, while the final model (Model 6) includes all of the different disclosures for listed associates. Because the firm-years of the sample represent a time series, serial correlation (autocorrelation) is a significant concern. As initial Durbin-Watson statistics suggest that significant serial correlation is present, reported results are autoregression results from maximum likelihood estimation ${ }^{4}$.

In all of the models the coefficients of book value of equity and net income from continuing operations are positive as predicted and significant at the one per cent level $(\mathrm{p}<0.001)$. Furthermore, the variables for loss firms as well as disclosed fair values are also positive and significant at the one per cent level throughout $(\mathrm{p}<0.001)$. Equity accounted carrying amounts are negative throughout and significant at the one per cent level $(p<0.001)$ in Model $1^{5}$.

However, when the disclosed net profit of listed associates is included in the regression (Model 2), the equity accounted carrying amounts are insignificant $(p=0.884)$, although still negative (-0.111). It may be that the disclosed net profit captures the information content of the equity accounted carrying amounts as it is negative (-4.739) and significant at the five per cent level $(\mathrm{p}=0.025)$. An indicator variable to control for lossmaking associates $\left(A P_{N e g}\right)$ is significant at the five per cent level $(\mathrm{p}=0.033)$ in Model 2. None of the other disclosure variables are significant when they are included individually (Models 3 to 5) and the equity accounted carrying amounts of listed associates are significant at the one per cent level.

\section{[INSER TABLE 4 ABOUT HERE]}

4 Autoregression with maximum likelihood estimation corrects for serial correlation and, as an added advantage, tends to be less sensitive to the impact of outliers, skewness and heteroskedasticity than ordinary least squares as it is a nonparametric estimation method.

5 The negative sign on the equity accounted carrying amounts remains if the difference between disclosed fair values and equity accounted carrying amounts are included, rather than the full disclosed fair values. The only exceptions are models where disclosed net profits are included, where the equity accounted carrying amounts are positive, but insignificant. All other inferences remain qualitatively unchanged. 
When all of the disclosure variables are included simultaneously (Model 6), only the disclosed net profit $(A P)$ and disclosed revenues $(A R)$ of the disclosure variables are significant at the one per cent level. In Model 6 the equity accounted carrying amounts are again insignificant $(\mathrm{p}=0.542)$. Although the coefficient of the disclosed total liabilities of listed associates is negative as predicted, in contrast to O'Hanlon and Taylor (2007) it is insignificant in all of the models in which it has been included. This could be due to the fact that O'Hanlon and Taylor (2007) do not distinguish between listed and unlisted associates. Interestingly, the lack of significance is not due to controlling for disclosed fair values, as the coefficient for disclosed liabilities remains insignificant if the model excludes the disclosed fair values.

The above findings suggest that individual elements of the disclosed summarised financial information are not always value-relevant, although the nature of the study and the resultant sample size limit the power of investigations. However, even if value-relevance for an individual element is not detected, the element might reduce the variance of the error term significantly (i.e. the element could be incrementally value-relevant). Therefore this study relies on a comparison of the error terms $(\varepsilon)$ of the various models to assess the incremental value-relevance of each disclosure, using the Vuong-test and the Dispersion-test. As the results of the two tests tend to be qualitatively similar in this study, in the interest of brevity, the subsequent discussions focus on the results of the Vuong-test. In Panel A of Table 5 each model is compared to the model immediately preceding to assess whether the latest model has incremental value-relevance. This panel shows that adding the disclosed net profit of listed associates to the base model (Model 2 versus Model 1) significantly reduces the variance in the error term of the model at the ten per cent level of significance $(p=0.051)$. Models 3 to 5 each fail to improve on the one immediately preceding, although the increase 
in error term variance is insignificant at conventional levels for all comparisons. However, Model 6 (which includes all of the disclosure variables) has a lower variance in the error term compared to Model 5, which is significant at the one per cent level $(p=0.007)$ and indicates that including all disclosures has incremental value-relevance.

Similar inferences are derived from Panel B of Table 5 where each model is compared to the base model (Model 1) which did not include any of the disclosure variables. Although each model has lower variance in the error term than the base model (all of the test statistics are negative), the decrease is insignificant in most cases apart from Model 2 and 6 . The decrease in error term variance when Model 2 is compared to the base model is significant at the ten per cent level $(\mathrm{p}=0.051)$, while this decrease is significant at the one per cent level $(p=0.006)$ when Model 6 is compared to the base model. These results imply that the elements of disclosed summarised financial information of listed associates have the greatest incremental value-relevance as a group.

Assessments of the statistical properties of the regression models reveal that the autoregression procedure is not completely successful in correcting serial correlation. Although the base model has successfully been corrected with no serial correlation detected at the five per cent level, all of the other models have inconclusive results based on DurbinWatson test statistics ${ }^{6}$. Test statistics are, however, close to the upper critical limits.

A graphical analysis does not suggest that heteroskedasticity is present in the sample and the distribution of residuals is approximately normal. However, multicollinearity is detected based on VIF-scores between disclosed net profit and equity accounted carrying amounts and between disclosed total assets and total liabilities of associates in Model 6 . Therefore, the regression is also run utilising the disclosed book value of equity of listed associates, rather than its comprising assets and liabilities. In untabulated results, this new

6 Utilising autoregression methods other than maximum likelihood similarly fail to correct for serial correlation and test statistics remain inconclusive. 
variable is negative, but insignificant $(\mathrm{p}=0.888)$, while the results for all of the other variables remain qualitatively unchanged from the reported results. As multicollinearity per definition only affects the interpretation of results for the variables where it is detected, the conclusions with respect to incremental value-relevance remains unchanged.

\section{[INSERT TABLE 5 ABOUT HERE]}

In summary, the findings are that disclosed summarised financial information of listed associates is incrementally value-relevant to their equity accounted carrying amounts and disclosed fair values as a group. In the section which follows, the findings of the main regression model are assessed for robustness, using various different model specifications and sample selection methodologies.

\section{Results of robustness tests}

In this section the results of various robustness tests are detailed. The robustness tests are grouped into subsections according to the elements which they address in order to facilitate the discussion process.

\subsection{Using market value of equity at reporting date}

The main multivariate regression results utilise market value of equity three months after reporting date as the dependent variable, as this allows for the natural delay in the dissemination of financial reporting information to investors. However, the regression is also run using the market value of equity at reporting date as the dependent variable. The independent variables continue to be specified as at reporting date.

Results (untabulated) are qualitatively unchanged from those of the main regression in general. The first exception is that the disclosed net profit $(A P)$ is now only significant at the 
ten per cent level $(p=0.070)$ in Model 2. The second exception is the indicator variable $A P_{\text {Neg, }}$ which is now only significant at the ten per cent level in Model $2(\mathrm{p}=0.078)$ and not at all in Model $6(\mathrm{p}=0.151)$. Lastly the coefficient for disclosed total assets is now positive in Model 6, but remains insignificant $(\mathrm{p}=0.858)$. When the variance in error terms of the different models is compared, the direction of decreases and increases remains unchanged, although levels of significance decline. Untabulated results reveal that, the variance in the error term of Model 2 is no longer significantly lower than that of the base model (Model 1) at conventional levels $(\mathrm{p}=0.143)$. However, Model 6 still improves on Model 5 at the five per cent level $(\mathrm{p}=0.038)$. Moreover, when Model 6 and Model 1 are compared, the Vuongtest reflects a decrease in error term variance significant at the five per cent level $(p=0.035)$ and the Dispersion Test a decrease significant at the ten per cent level $(p=0.060)$.

Overall, results of this robustness test are therefore consistent with those of the main regression. Although the levels of significance decrease somewhat when the variance of various models are compared, results continue to suggest that disclosed summarised financial information of listed associates have the greatest incremental value-relevance when it is considered collectively.

\subsection{Excluding loss firm-years and certain industries}

The indicator variable for loss firms is significant in the main regressions. As a result, a robustness test excluding these firms appears warranted. As loss making associates are likely to be priced differently from other associates, profitable firms with loss making associates are also excluded. Furthermore, this robustness test excludes financial services, mining and utility firms from the sample. The descriptive statistics highlighted the skew induced by financial services firms and findings by Barth and Clinch (1998) suggest that the associates of mining firms are priced differently from those of other firms. Utility firms face a heavy regulatory burden which could impact on results of the main regression. 
Results are detailed in Table 6 and show that the equity accounted carrying amounts of listed associates are now generally insignificant, but remain negative in all but two models (Models 4 and 5). Disclosed fair values of listed associates are positive and significant at the one per cent level in all of the models, except when disclosed net profit of associates is included in the model. When disclosed net profit is included (Models 2 and 6) disclosed fair values of listed associates have a negative sign. Although mildly significant in Model 6 $(p=0.107)$, this variable is insignificant when only the disclosed net profit of listed associates are included in Model $2(\mathrm{p}=0.698)$.

\section{[INSERT TABLE 6 ABOUT HERE]}

The disclosure variables are all insignificant when included individually, with the exception of disclosed net profit. When the disclosed net profit is added to the base model it is positive $(15.737)$ and significant at the one per cent level $(p=0.007)$. This change in sign from the main regression results is also present when all of the elements of the disclosed summarised financial information are added to the base model (Model 6). Here the disclosed net profit of listed associates is the only disclosure variable with statistical significance $(p=0.004)$. In comparison to the main regression results, the disclosed revenues of listed associates are no longer significant at conventional levels $(p=0.148)$, although the sign of the variable is consistent with that of the main regression. The significance of the disclosed total liabilities improves from the main regression model, but the variable remains insignificant at conventional levels $(\mathrm{p}=0.158)$. Disclosed total assets of listed associates remain insignificant $(\mathrm{p}=0.679)$, although the variable is now positive $(0.323)$.

These results suggest that the disclosed net profit of listed associates is value-relevant on its own or in combination with the rest of the disclosed summarised financial information. 
However, incremental value-relevance is assessed with reference to the change in variance in the error term of the various regression models in this study, tabulated in Table 7 . This table shows that adding disclosed net profit of listed associates to the base model reduces the error term variance of the model. However, this decrease is now mildly significant at best $(\mathrm{p}=0.135)$. Comparing the successive models (Panel A of Table 7) reflects that the change in error term variance between successive models is not significant, with the exception of comparing Model 6 (which includes all of the disclosure variables) to Model 5 (which includes only the disclosed total liabilities of listed associates). This decrease in the variance of the error term is significant at the ten per cent level for both the Vuong-test and Dispersion-test.

\section{[INSERT TABLE 7 ABOUT HERE]}

Panel B of Table 7 shows that a model containing any of the disclosure variables is an improvement on the base model, but that the decrease in error term variance is mostly insignificant. In fact, the only decrease significant at conventional levels is when the base model is compared with the model including all of the disclosure variables (Model 6). Here the decrease in error term variance is significant at the ten per cent level $(p=0.054)$.

Consequently, results from the robustness test in this section suggest that the support for inferences is weaker when loss firms and firms operating in the mining, financial services and utility industries are excluded from the sample. However, results continue to suggest that including all of the disclosed summarised financial information in the model is preferable to including a single element thereof. By implication, disclosed summarised financial information of listed associates has the greatest incremental value-relevance when all elements are included. 


\subsection{Additional assessment of the impact of skew in the data}

To assess the impact of skew in the sample on the results of the main regression, separately from the impact of industry, an additional robustness test is performed where all scale variables are specified using the natural log thereof, rather than scaling by number of shares outstanding. Results (untabulated) for the control variables remain unchanged from that of the main regression, with the exception of equity accounted carrying amounts which are now insignificant in all model specifications. In respect of the disclosure variables, results for disclosed profit or loss $(A P)$ and disclosed revenue $(A R)$ of listed associates remain qualitatively unchanged from the main regression. Interestingly, disclosed total assets and disclosed total liabilities of listed associates are now positive and significant at the five per cent level or better when included separately. Including all disclosure variables simultaneously (Model 6) results in an insignificant negative coefficient for disclosed revenue, while disclosed total liabilities are now positive and significant at the five per cent level $(\mathrm{p}=0.041)$

However, more importantly, most of the inferences from incremental value-relevance changes are qualitatively unchanged from the main regression. The only difference is that the variance in the error term of Model 3 (containing $A R$ ) is now significantly higher than that of Model 2 at the one per cent level $(p=0.003)$. However, the variance in the error term of Model 1 still improves on the base model at the one per cent level of significance in both the Vuong $(p=0.002)$ and Dispersion-tests $(p=0.006)$, while Model 6 (the full model) likewise improves on Model 5 as well as the base model at the one per cent level of significance. Consequently the results show that eliminating skew does not weaken the main regression results and that industry specific characteristics explain the results of the previous robustness test. The main finding remains that the disclosed summarised financial information of listed associates have the greatest incremental value-relevance as a group. 


\section{Contribution and implications of the paper}

This study contributes to the existing literature due to its explicit focus on the incremental value-relevance of disclosed summarised financial information. The first important contribution of this paper is that, in contrast to prior research (Baumann, 2003; O'Hanlon \& Taylor, 2007, Richardson et al., 2012), disclosed fair values of listed associates are controlled for. As disclosed fair values should incorporate all available financial information relating to the listed associate, this is an important control variable. Furthermore, prior research considers each disclosure in isolation, while this paper investigates all disclosures related to investments in equity accounted listed associates simultaneously. Importantly, results show that disclosed summarised financial information variables have the greatest incremental value-relevance as a group. By implication, those disclosures excluded from prior research models probably represent omitted correlated variables. In particular, findings imply that each element of disclosed summarised financial information is incrementally value-relevant as a component of the whole.

The group of variables could be used to determine an intrinsic value for investments in listed associates. As the variables are incrementally value-relevant as a group, investors therefore value investments in listed associates by using the underlying accounting information to perform a separate valuation, rather than using the market values (fair values) of the associates directly. This is of interest to those performing or researching equity valuations, as many valuation texts argue that the unadjusted fair value of the listed associate should be incorporated into the valuation of the reporting entity (Koller, Goedhart, \& Wessels, 2010; Nissim \& Penman, 2001). Importantly the findings of this study also imply that accounting information of listed associates remains value-relevant, even when alternative market-based valuations are available. This is important in the context of the fair value accounting debate, where the scope of fair value accounting continues to grow. 


\section{Conclusion}

The hypothesis of this study (in null form) is that the disclosures of summarised financial information of listed associates (i.e. total assets, total liabilities, revenue and profit or loss) are not value-relevant. Findings are based using a sample selected from the 250 largest firms listed in South Africa, Australia and the United Kingdom. Results of this paper can therefore only be generalised to larger firms with listed associates reporting under International Financial Reporting Standards (IFRS), as smaller firms may be subject to other valuation dynamics.

Results suggest that individual items of disclosed summarised financial information of listed associates are not consistently value-relevant. However, disclosed summarised financial information of listed associates collectively has incremental value-relevance, which implies that that this information is used by equity investors to value a firm's investments in its listed associates. In addition, the disclosed summarised financial information offers incremental information content above the equity accounted carrying amounts and disclosed fair values. This suggests that investors utilise information captured by the alternative measurement bases, rather than the measurement bases themselves, to determine an intrinsic value of investments in associates.

Incremental value-relevance results are robust to specifying the dependent variable at reporting date, as opposed to three months thereafter and to a specification designed to reduce skew in the sample. However, results are weaker when the sample excludes loss firms and financial services, mining and utility firms. Although conclusions are similar to those of the main regression, levels of significance are lower. A possible reason for the decline in significance could be that accurate valuations of investments in listed associates have greater importance for investors when a firm is suffering losses or operating in the financial services, mining or utility industries, which industries tend to carry greater operational risk. 
The findings of this paper contribute to the existing literature as they provide evidence of incremental value-relevance and control for a greater number of disclosure variables. In addition, findings imply that the underlying accounting information of listed associates remains value-relevant and is incorporated into an intrinsic value by investors, even where an alternative market-based measurement is available.

\section{References}

Ashbough, H. \& Olsson, P. (2002). An exploratory study of the valuation properties of crosslisted firms' IAS and US GAAP earnings and book values. Accounting Review, 77(1), 107-126.

Ball, R., Robin, A. \& Wu, J.S. (2003). Incentives versus standards: properties of accounting income in four East Asian countries. Journal of Accounting and Economics, 36, 235270.

Barth, M.E., Beaver, W.H. \& Landsman, W.R. (2001). The relevance of the value-relevance literature for financial accounting standard setting: another view. Journal of Accounting and Economics, 31, 77-104.

Barth, M.E. \& Clinch, G. (1998). Revalued financial, tangible and intangible assets: associations with share prices and non-market-based value estimates. Journal of Accounting Research, 36, 199-233.

Barth, M.E. \& Clinch, G. (2009). Scale effects in capital markets-based accounting research. Journal of Business Finance and Accounting, 36(3) \& (4), 253-288.

Baumann, M.P. (2003). The impact and valuation of off-balance-sheet activities concealed by equity method accounting. Accounting Horizons, 17(4), 303-314.

Dechow, P.M. (1994). Accounting earnings and cash flows as measures of firm performance: the role of accounting accruals. Journal of Accounting and Economics, 18, 3-42.

Graham, R.C., Lefanowicz, C.E. \& Petroni, K.R. (2003). The value-relevance of equity method fair value disclosures. Journal of Business Finance and Accounting, 30(7) \& (8), 1065-1088.

$\mathrm{Gu}, \mathrm{Z}$. (2007). Across-sample incomparability of $\mathrm{R}^{2} \mathrm{~s}$ and additional evidence on valuerelevance changes over time. Journal of Business Finance and Accounting, 34(7) \& (8), 1073-1098.

IASB - see International Accounting Standards Board 
International Accounting Standards Board (2003). Investments in associates. December, London. IFRS Foundation.

International Accounting Standards Board (2010). Conceptual framework for financial reporting. September. London. IFRS Foundation.

International Accounting Standards Board (2011). Investments in associates and joint ventures. May. London. IFRS Foundation.

Nissim, D. \& Penman, S.H. (2001). Ratio analysis and equity valuation: from research to practice. Review of Accounting Studies, 6, 109-154.

Nobes, C. (2002). An analysis of the international development of the equity method. Abacus, 38(1), 16-45.

Koller, T., Goedhart, M. \& Wessels, D. (2010). Valuation: measuring and managing the value of companies. New Jersey. John Wiley \& Sons Inc.

O'Hanlon, J. \& Taylor, P. (2007). The value-relevance of disclosures of liabilities of equity accounted investees: UK evidence. Accounting and Business Research, 37(4), 267284.

Pouraghajan, A., Emamgholipour, M., Niazi, F. \& Samakosh, A. (2012). Information content of earnings and operating cash flows: evidence from the Tehran stock exchange. International Journal of Economics and Finance, 4(7), 41-51.

Richardson, A.W., Roubi, R.R. \& Soonawalla, K. (2012). Decline in financial reporting for joint ventures? Canadian evidence on removal of financial reporting choice. European Accounting Review, 21(2), 373-393.

Soonawalla, K. (2006). Accounting for joint ventures and associates in Canada, UK, and US: do US rules hide information? Journal of Business Finance and Accounting, 33(3) \& (4), 395-417.

Vuong, Q.H. (1989). Likelihood ratio tests for model selection and non-nested hypotheses. Econometrica, 57(2), 307-333. 
Table 1: Reconciliation of sample firm-years

\begin{tabular}{|lc|}
\hline Number of firm-years listed for full year & Total \\
No investment in associate & 4154 \\
No investment in a listed associate & $(2331)$ \\
Incomplete disclosure in the financial statements & $(745)$ \\
Investments in associates carried at fair value & $(740)$ \\
Financial statements not available & $(27)$ \\
Other & $(36)$ \\
Sample firm-years for the study & $(40)$ \\
Number of unique firms & 235 \\
\hline \hline
\end{tabular}


Table 2: Descriptive statistics

\begin{tabular}{|c|c|c|c|c|c|c|}
\hline & $\mathbf{N}$ & $\begin{array}{c}\text { Mean } \\
\text { ZAR million }\end{array}$ & $\begin{array}{c}\text { Median } \\
\text { ZAR million }\end{array}$ & $\begin{array}{c}\text { Standard Deviation } \\
\text { ZAR million }\end{array}$ & $\begin{array}{c}\text { Minimum } \\
\text { ZAR million }\end{array}$ & $\begin{array}{c}\text { Maximum } \\
\text { ZAR million }\end{array}$ \\
\hline \multicolumn{7}{|c|}{ Panel A: Descriptive statistics for unscaled variables } \\
\hline $\mathrm{MV}_{\mathrm{E}}$ & 235 & 155311 & 39987 & 273564 & 288 & 1590911 \\
\hline$B V_{\text {Excl }}$ & 235 & 66986 & 21928 & 160613 & -31585 & 1141598 \\
\hline NI & 235 & 10100 & 2485 & 20037 & -8065 & 135561 \\
\hline $\mathrm{ASC}_{\mathrm{CA}}$ & 235 & 6092 & 872 & 17529 & 0 & 135918 \\
\hline $\mathrm{ASC}_{\mathrm{FV}}$ & 235 & 13645 & 1017 & 39363 & 3 & 267401 \\
\hline AP & 235 & 3604 & 132 & 13457 & -3103 & 114417 \\
\hline AR & 235 & 21204 & 968 & 77145 & 0 & 708305 \\
\hline ATA & 235 & 216846 & 4892 & 1150720 & 5 & 10816217 \\
\hline ATL & 235 & 186799 & 1957 & 1072227 & 2 & 10129655 \\
\hline \multicolumn{7}{|c|}{ Panel B: Descriptive statistics for variables scaled by number of shares outstanding } \\
\hline $\mathrm{MV}_{\mathrm{E}}$ & 235 & 97.738 & 53.537 & 129.980 & 2.000 & 1144.500 \\
\hline $\mathrm{BV}_{\text {Excl }}$ & 235 & 38.281 & 23.005 & 42.579 & -4.073 & 253.664 \\
\hline NI & 235 & 5.272 & 2.970 & 7.318 & -15.394 & 49.630 \\
\hline $\mathrm{ASC}_{\mathrm{CA}}$ & 235 & 3.850 & 0.903 & 9.726 & 0.000 & 83.874 \\
\hline $\mathrm{ASC}_{\mathrm{FV}}$ & 235 & 9.142 & 1.082 & 30.260 & 0.004 & 338.677 \\
\hline AP & 235 & 1.533 & 0.176 & 4.192 & -3.560 & 26.911 \\
\hline AR & 235 & 8.922 & 1.221 & 18.250 & 0.000 & 106.688 \\
\hline ATA & 235 & 45.241 & 6.445 & 120.122 & 0.012 & 716.422 \\
\hline ATL & 235 & 33.610 & 2.286 & 109.375 & 0.002 & 660.724 \\
\hline $\mathrm{MV}_{\mathrm{E}}$ & \multicolumn{6}{|c|}{ Market value of equity, three months after reporting date } \\
\hline$B V_{\text {Excl }}$ & \multicolumn{6}{|c|}{ Book value of equity, excluding the equity accounted carrying amounts of listed associates } \\
\hline NI & \multicolumn{6}{|c|}{ Net income from continuing operations, attributable to ordinary shareholders of the parent } \\
\hline $\mathrm{ASC}_{\mathrm{CA}}$ & \multicolumn{6}{|c|}{ Equity accounted carrying amounts of the listed associates } \\
\hline $\mathrm{ASC}_{\mathrm{FV}}$ & \multicolumn{6}{|c|}{ Disclosed fair values of the listed associates } \\
\hline AP & \multicolumn{6}{|c|}{ Disclosed net profit of the listed associates } \\
\hline $\mathrm{AR}$ & \multicolumn{6}{|c|}{ Disclosed revenue of the listed associates } \\
\hline ATA & \multicolumn{6}{|c|}{ Disclosed total assets of the listed associates } \\
\hline ATL & \multicolumn{6}{|c|}{ Disclosed total liabilities of the listed associates } \\
\hline
\end{tabular}


Table 3: Univariate correlations

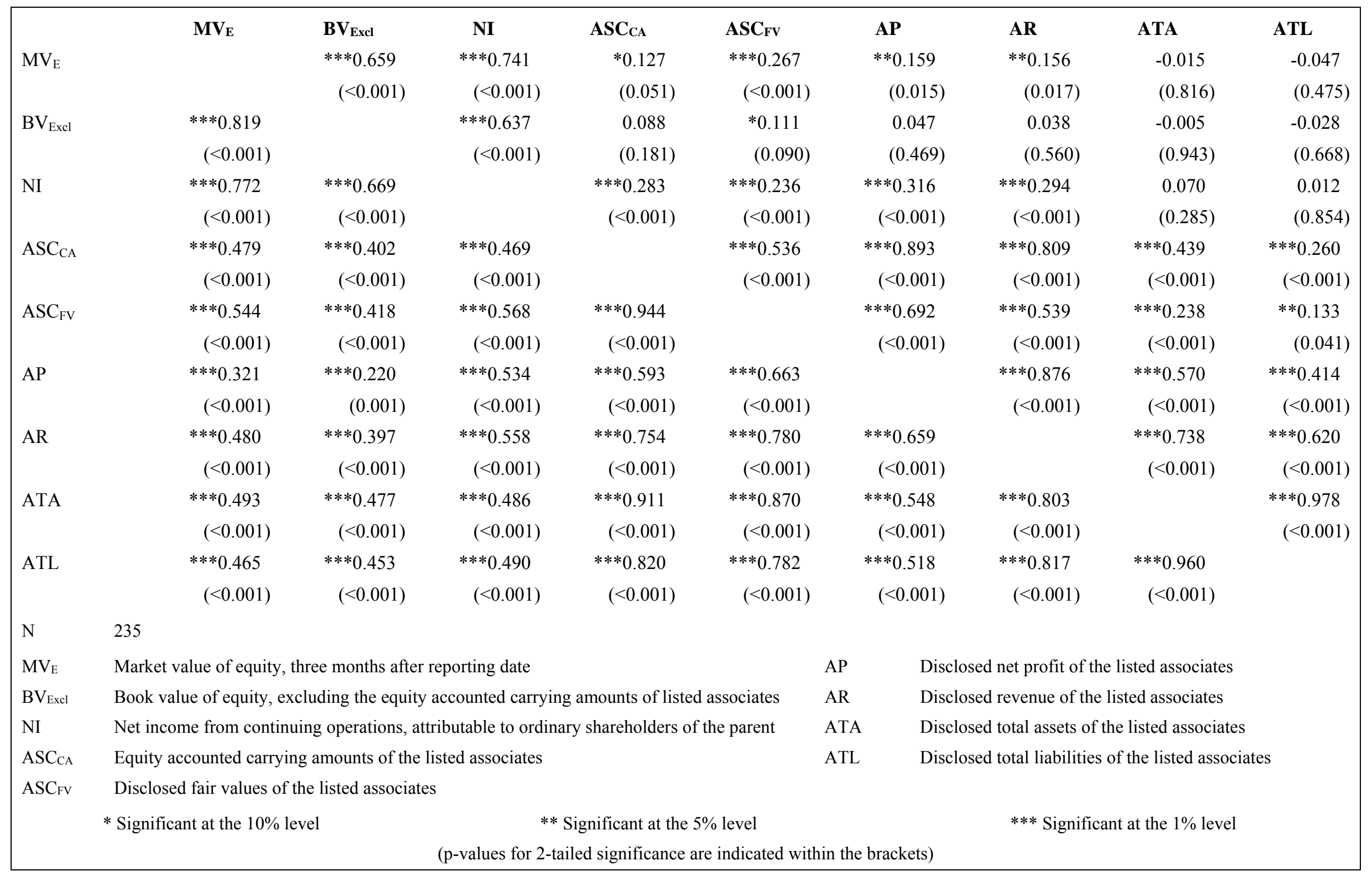


Table 4: Regression findings

\begin{tabular}{|c|c|c|c|c|c|c|c|}
\hline \multicolumn{8}{|c|}{$\mathrm{MV}_{\mathrm{E}}=\alpha_{0}+\alpha_{1} \Sigma$ Year $+\alpha_{2} \Sigma \mathrm{CTRY}+\beta_{1} \mathrm{BV}_{\mathrm{Excl}}+\beta_{2} \mathrm{NI}+\beta_{3} \mathrm{Neg}+\beta_{4} \mathrm{ASC}_{\mathrm{CA}}+\beta_{5} \mathrm{ASC}_{\mathrm{FV}}+\beta_{6} \mathrm{DISCL}+\varepsilon$} \\
\hline & $\begin{array}{l}\text { Predicted } \\
\text { Sign }\end{array}$ & Model 1 & Model 2 & Model 3 & Model 4 & Model 5 & Model 6 \\
\hline $\mathrm{BV}_{\text {Excl }}$ & + & $\begin{array}{r}* * * 0.929 \\
(<0.001)\end{array}$ & $\begin{array}{l}* * * 0.846 \\
(<0.001)\end{array}$ & $\begin{array}{r}* * * 0.947 \\
(<0.001)\end{array}$ & $\begin{array}{l}* * * 0.930 \\
(<0.001)\end{array}$ & $\begin{array}{r}* * * 0.930 \\
(<0.001)\end{array}$ & $\begin{array}{r}* * * 0.900 \\
(<0.001)\end{array}$ \\
\hline NI & + & $\begin{array}{r}* * * 9.257 \\
(<0.001)\end{array}$ & $\begin{array}{l}* * * 9.607 \\
(<0.001)\end{array}$ & $\begin{array}{r}* * * 9.142 \\
(<0.001)\end{array}$ & $\begin{array}{l}* * * 9.200 \\
(<0.001)\end{array}$ & $\begin{array}{r}* * * 9.209 \\
(<0.001)\end{array}$ & $\begin{array}{r}* * * 9.003 \\
(<0.001)\end{array}$ \\
\hline Neg & $+1-$ & $\begin{array}{r}* * * 55.842 \\
(<0.001)\end{array}$ & $\begin{array}{r}* * * 46.247 \\
(<0.001)\end{array}$ & $\begin{array}{r}* * * 55.928 \\
(<0.001)\end{array}$ & $\begin{array}{r}* * * 55.242 \\
\quad(<0.001)\end{array}$ & $\begin{array}{r}* * * 55.334 \\
(<0.001)\end{array}$ & $\begin{aligned} * * * 44.903 \\
(<0.001)\end{aligned}$ \\
\hline $\mathrm{ASC}_{\mathrm{CA}}$ & $+/-$ & $\begin{array}{r}* * *-1.559 \\
\quad(<0.001)\end{array}$ & $\begin{array}{l}-0.111 \\
(0.884)\end{array}$ & $\begin{array}{r}* * *-1.954 \\
(0.001)\end{array}$ & $\begin{array}{r}* * *-1.450 \\
(0.001)\end{array}$ & $\begin{array}{r}* * *_{-} 1.504 \\
(<0.001)\end{array}$ & $\begin{array}{l}-0.609 \\
(0.542)\end{array}$ \\
\hline $\mathrm{ASC}_{\mathrm{FV}}$ & $+/-$ & $\begin{array}{r}* * * 0.831 \\
(<0.001)\end{array}$ & $\begin{array}{l}* * * 1.042 \\
(<0.001)\end{array}$ & $\begin{array}{r}* * * 0.805 \\
(<0.001)\end{array}$ & $\begin{array}{l}* * * 0.831 \\
(<0.001)\end{array}$ & $\begin{array}{r}* * * 0.830 \\
(<0.001)\end{array}$ & $\begin{array}{r}* * * 1.065 \\
(<0.001)\end{array}$ \\
\hline AP & $+/-$ & & $\begin{array}{r}* *-4.739 \\
(0.025)\end{array}$ & & & & $\begin{array}{r}* * *-8.390 \\
(0.002)\end{array}$ \\
\hline $\mathrm{AP}_{\mathrm{Neg}}$ & $+/-$ & & $\begin{array}{r}* * 17.826 \\
(0.033)\end{array}$ & & & & $\begin{array}{r}* 14.494 \\
(0.080)\end{array}$ \\
\hline AR & $+/-$ & & & $\begin{array}{c}0.316 \\
(0.295)\end{array}$ & & & $\begin{array}{r}* * * 1.523 \\
(0.001)\end{array}$ \\
\hline ATA & $+/-$ & & & & $\begin{array}{l}-0.020 \\
(0.496)\end{array}$ & & $\begin{array}{l}-0.041 \\
(0.891)\end{array}$ \\
\hline ATL & - & & & & & $\begin{array}{l}-0.018 \\
(0.544)\end{array}$ & $\begin{array}{l}-0.021 \\
(0.946)\end{array}$ \\
\hline $\mathrm{N}$ & & 230 & 230 & 230 & 230 & 230 & 230 \\
\hline Structural $\mathrm{R}^{2}$ & & $76.9 \%$ & $78.2 \%$ & $77.0 \%$ & $76.9 \%$ & $76.9 \%$ & $79.5 \%$ \\
\hline $\mathrm{MV}_{\mathrm{E}}$ & Market value of ec & ity, three mor & ths after repo & g date & & & \\
\hline$B V_{\text {Excl }}$ & Book value of equit & $y$, excluding $t$ & e equity accou & nted carrying & amounts of liste & ed associates & \\
\hline NI & Net income from co & ntinuing oper & tions, attributa & ble to ordinary & shareholders o & $f$ the parent & \\
\hline Neg & Indicator variable s & t to one if a $\mathrm{f}$ & m-year reflect & a loss from c & ontinuing oper: & ations and zero & otherwise \\
\hline $\mathrm{ASC}_{\mathrm{CA}}$ & Equity accounted ca & rrying amoun & $\mathrm{s}$ of the listed $\mathrm{c}$ & issociates & & & \\
\hline $\mathrm{ASC}_{\mathrm{FV}}$ & Disclosed fair value & $\mathrm{s}$ of the listed & associates & & & & \\
\hline AP & Disclosed net profit & of the listed a & sociates & & & & \\
\hline $\mathrm{AP}_{\mathrm{Neg}}$ & Indicator variable s & $t$ to one if a $n$ & toss from list & ed associates i & $\mathrm{s}$ disclosed and & zero otherwis & \\
\hline AR & Disclosed revenue & $f$ the listed as & ociates & & & & \\
\hline ATA & Disclosed total asse & ts of the listed & associates & & & & \\
\hline ATL & Disclosed total liab & lities of the lis & ted associates & & & & \\
\hline $\begin{array}{r}* \text { Signific } \\
\text { (Autor }\end{array}$ & $\begin{array}{l}\text { icant at the } 10 \% \text { lev } \\
\text { regression maximur }\end{array}$ & a likelihood $\mathrm{p}$ & $\begin{array}{l}\text { Significant a } \\
\text { values for } 2-\mathrm{t}\end{array}$ & $\begin{array}{l}\text { the } 5 \% \text { level } \\
\text { iled significan }\end{array}$ & $\begin{array}{r}* * * \mathrm{~S} \\
\text { are indicate }\end{array}$ & $\begin{array}{l}\text { gnificant at the } \\
\text { within the bra }\end{array}$ & $\begin{array}{l}1 \% \text { level } \\
\text { ckets) }\end{array}$ \\
\hline
\end{tabular}


Table 5: Comparison of the regression findings

\begin{tabular}{|c|c|c|c|c|}
\hline \multicolumn{5}{|c|}{$\mathrm{MV}_{\mathrm{E}}=\alpha_{0}+\alpha_{1} \Sigma$ Year $+\alpha_{2} \Sigma \mathrm{CTRY}+\beta_{1} \mathrm{BV}_{\mathrm{Excl}}+\beta_{2} \mathrm{NI}+\beta_{3} \mathrm{Neg}+\beta_{4} \mathrm{ASC}_{\mathrm{CA}}+\beta_{5} \mathrm{ASC}_{\mathrm{FV}}+\beta_{6} \mathrm{DISCL}+\varepsilon$} \\
\hline & $\mathbf{N}$ & $\begin{array}{c}\text { Mean sum of } \\
\text { squares of residual }\end{array}$ & $\begin{array}{c}\text { Dispersion-test } \\
\text { (t-statistic) }\end{array}$ & $\begin{array}{l}\text { Vuong-test } \\
\text { (t-statistic) }\end{array}$ \\
\hline Model 1 & 230 & 2069 & & \\
\hline Model 2 & 230 & 1945 & $\begin{array}{r}*_{-}-1.773 \\
(0.078)\end{array}$ & $\begin{array}{r}*-1.961 \\
\quad(0.051)\end{array}$ \\
\hline Model 3 & 230 & 2057 & $\begin{array}{l}1.500 \\
(0.135)\end{array}$ & $\begin{array}{l}1.610 \\
(0.109)\end{array}$ \\
\hline Model 4 & 230 & 2065 & $\begin{array}{c}0.441 \\
(0.659)\end{array}$ & $\begin{array}{l}0.446 \\
(0.656)\end{array}$ \\
\hline Model 5 & 230 & 2066 & $\begin{array}{c}0.659 \\
(0.510)\end{array}$ & $\begin{array}{l}0.678 \\
(0.498)\end{array}$ \\
\hline Model 6 & 230 & 1834 & $\begin{array}{r}* *-2.366 \\
(0.019)\end{array}$ & $\begin{array}{r}* * *-2.731 \\
(0.007)\end{array}$ \\
\hline \multicolumn{5}{|c|}{ Panel B: Comparison of each model to the base model } \\
\hline & $\mathbf{N}$ & $\begin{array}{l}\text { Change in mean } \\
\text { sum of squares of } \\
\text { residual }\end{array}$ & $\begin{array}{c}\text { Dispersion-test } \\
\text { (t-statistic) }\end{array}$ & $\begin{array}{l}\text { Vuong-test } \\
\text { (t-statistic) }\end{array}$ \\
\hline Model 2 vs 1 & 230 & -124 & $\begin{array}{r}*_{-}-1.773 \\
(0.078)\end{array}$ & $\begin{array}{r}*-1.961 \\
(0.051)\end{array}$ \\
\hline Model 3 vs 1 & 230 & -12 & $\begin{array}{l}-0.842 \\
(0.401)\end{array}$ & $\begin{array}{l}-0.864 \\
(0.389)\end{array}$ \\
\hline Model 4 vs 1 & 230 & -4 & $\begin{array}{l}-0.598 \\
(0.551)\end{array}$ & $\begin{array}{l}-0.604 \\
(0.547)\end{array}$ \\
\hline Model 5 vs 1 & 230 & -3 & $\begin{array}{l}-0.537 \\
(0.592)\end{array}$ & $\begin{array}{l}-0.541 \\
(0.589)\end{array}$ \\
\hline Model 6 vs 1 & 230 & -235 & $\begin{array}{r}* *-2.401 \\
\quad(0.017)\end{array}$ & $\begin{array}{r}* * *-2.780 \\
(0.006)\end{array}$ \\
\hline Model 1 & \multicolumn{4}{|c|}{ Containing only the equity accounted carrying amounts and disclosed fair values of listed associates } \\
\hline Model 2 & \multicolumn{4}{|c|}{ Containing only the disclosed net profit of the listed associates } \\
\hline Model 3 & \multicolumn{4}{|c|}{ Containing only the disclosed revenue of the listed associates } \\
\hline Model 4 & \multicolumn{4}{|c|}{ Containing only the disclosed total assets of the listed associates } \\
\hline Model 5 & \multicolumn{4}{|c|}{ Containing only the disclosed total liabilities of the listed associates } \\
\hline \multicolumn{5}{|c|}{$\begin{array}{l}\text { The Dispersion-test assesses the significance of changes in the variance of the error term }(\varepsilon) \text { using unstandardized } \\
\text { residuals from each model in a paired sample ANOVA. }\end{array}$} \\
\hline \multicolumn{5}{|c|}{$\begin{array}{l}\text { The Vuong-test (Vuong, 1989) is directional. Positive test statistics indicate that the first model is superior to the } \\
\text { second model, while negative test statistics indicate that the second model is superior to the first model. }\end{array}$} \\
\hline * Significa & $\begin{array}{l}t \text { at the } 10 \% \text { level } \\
\qquad(\mathrm{p} \text {-values }\end{array}$ & $\begin{array}{l}\text { ** Significant at the } 5 \% \\
\text { iled significance are indi }\end{array}$ & $\begin{array}{l}\text { vel } \\
\text { d within the brackets) }\end{array}$ & at the $1 \%$ level \\
\hline
\end{tabular}


Table 6: Regression findings when loss firm-years and certain industries are excluded

\begin{tabular}{|c|c|c|c|c|c|c|c|}
\hline \multicolumn{8}{|c|}{$\mathrm{MV}_{\mathrm{E}}=\alpha_{0}+\alpha_{1} \Sigma$ Year $+\alpha_{2} \Sigma \mathrm{CTRY}+\beta_{1} \mathrm{BV}_{\mathrm{Excl}}+\beta_{2} \mathrm{NI}+\beta_{3} \mathrm{ASC}_{\mathrm{CA}}+\beta_{4} \mathrm{ASC}_{\mathrm{FV}}+\beta_{5} \mathrm{DISCL}+\varepsilon$} \\
\hline \multirow[b]{2}{*}{$B V_{\text {Excl }}$} & $\begin{array}{l}\text { Predicted } \\
\text { Sign }\end{array}$ & Model 1 & Model 2 & Model 3 & Model 4 & Model 5 & Model 6 \\
\hline & + & $\begin{array}{r}* * * 0.460 \\
(<0.001)\end{array}$ & $\begin{array}{r}* * * 0.504 \\
(<0.001)\end{array}$ & $\begin{aligned} * * * 0.481 \\
(<0.001)\end{aligned}$ & $\begin{array}{r}* * * 0.457 \\
(<0.001)\end{array}$ & $\begin{array}{r}* * * 0.449 \\
(<0.001)\end{array}$ & $\begin{array}{r}* * * 0.488 \\
(<0.001)\end{array}$ \\
\hline NI & + & $\begin{array}{r}* * * 12.453 \\
\quad(<0.001)\end{array}$ & $\begin{aligned} * * * 11.530 \\
\quad(<0.001)\end{aligned}$ & $\begin{array}{rl}* * * & 11.842 \\
(<0.001)\end{array}$ & $\begin{aligned} * * * 12.445 \\
\quad(<0.001)\end{aligned}$ & $\begin{aligned} * * * 12.518 \\
(<0.001)\end{aligned}$ & $\begin{aligned} * * * 10.905 \\
(<0.001)\end{aligned}$ \\
\hline $\mathrm{ASC}_{\mathrm{CA}}$ & $+/-$ & $\begin{array}{l}-0.247 \\
(0.844)\end{array}$ & $\begin{array}{r}* *_{-}-3.231 \\
(0.049)\end{array}$ & $\begin{array}{l}-1.707 \\
(0.294)\end{array}$ & $\begin{array}{c}1.140 \\
(0.611)\end{array}$ & $\begin{array}{c}1.031 \\
(0.632)\end{array}$ & $\begin{array}{l}-0.972 \\
(0.657)\end{array}$ \\
\hline $\mathrm{ASC}_{\mathrm{FV}}$ & $+/-$ & $\begin{array}{c}* * * 0.622 \\
(<0.001)\end{array}$ & $\begin{array}{l}-0.116 \\
(0.698)\end{array}$ & $\begin{array}{c}* * * 0.619 \\
(<0.001)\end{array}$ & $\begin{array}{r}* * * 0.577 \\
\quad(0.001)\end{array}$ & $\begin{array}{r}* * * 0.544 \\
\quad(0.004)\end{array}$ & $\begin{array}{l}-0.595 \\
(0.107)\end{array}$ \\
\hline AP & $+/-$ & & $\begin{array}{rl}* * * & 15.737 \\
(0.007)\end{array}$ & & & & $\begin{array}{r}* * * 18.597 \\
(0.004)\end{array}$ \\
\hline $\mathrm{AR}$ & $+/-$ & & & $\begin{array}{c}0.927 \\
(0.155)\end{array}$ & & & $\begin{array}{c}1.173 \\
(0.148)\end{array}$ \\
\hline ATA & $+/-$ & & & & $\begin{array}{l}-0.241 \\
(0.452)\end{array}$ & & $\begin{array}{c}0.323 \\
(0.679)\end{array}$ \\
\hline ATL & - & & & & & $\begin{array}{l}-0.423 \\
(0.459)\end{array}$ & $\begin{array}{l}-2.145 \\
(0.158)\end{array}$ \\
\hline \multirow{2}{*}{\multicolumn{2}{|c|}{$\begin{array}{l}\mathrm{N} \\
\text { Structural R2 }\end{array}$}} & 93 & 93 & 93 & 93 & 93 & 93 \\
\hline & & $90.5 \%$ & $91.3 \%$ & $90.7 \%$ & $90.6 \%$ & $90.6 \%$ & $92.1 \%$ \\
\hline $\mathrm{MV}_{\mathrm{E}}$ & \multicolumn{7}{|c|}{ Market value of equity, three months after reporting date } \\
\hline$B V_{\text {Excl }}$ & \multicolumn{7}{|c|}{ Book value of equity, excluding the equity accounted carrying amounts of listed associates } \\
\hline NI & \multicolumn{7}{|c|}{ Net income from continuing operations, attributable to ordinary shareholders of the parent } \\
\hline $\mathrm{ASC}_{\mathrm{CA}}$ & \multicolumn{7}{|c|}{ Equity accounted carrying amounts of the listed associates } \\
\hline $\mathrm{ASC}_{\mathrm{FV}}$ & \multicolumn{7}{|c|}{ Disclosed fair values of the listed associates } \\
\hline AP & \multicolumn{7}{|c|}{ Disclosed net profit of the listed associates } \\
\hline AR & \multicolumn{7}{|c|}{ Disclosed revenue of the listed associates } \\
\hline ATA & \multicolumn{7}{|c|}{ Disclosed total assets of the listed associates } \\
\hline ATL & \multicolumn{7}{|c|}{ Disclosed total liabilities of the listed associates } \\
\hline \multicolumn{8}{|c|}{ Firms in financial services, mining and utilities have been eliminated, using industry classifications per Datastream. } \\
\hline \multicolumn{3}{|c|}{$\begin{array}{l}* \text { Significant at the } 10 \% \text { level } \\
\quad \text { (Autoregression maximum li }\end{array}$} & $\begin{array}{l}\text { Significant at } \\
\text {-values for } 2 \text {-ta }\end{array}$ & $\begin{array}{l}\text { the } 5 \% \text { level } \\
\text { iled significan }\end{array}$ & \multicolumn{3}{|c|}{$\begin{array}{l}* * * \text { Significant at the } 1 \% \text { level } \\
\text { ndicated within the brackets) }\end{array}$} \\
\hline
\end{tabular}


Table 7: Comparison of the regression findings when loss firm-years and certain industries are excluded

$$
\mathrm{MV}_{\mathrm{E}}=\alpha_{0}+\alpha_{1} \Sigma \text { Year }+\alpha_{2} \Sigma \mathrm{CTRY}+\beta_{1} \mathrm{BV}_{\mathrm{Excl}}+\beta_{2} \mathrm{NI}+\beta_{3} \mathrm{Neg}+\beta_{4} \mathrm{ASC}_{\mathrm{CA}}+\beta_{5} \mathrm{ASC}_{\mathrm{FV}}+\beta_{6} \mathrm{DISCL}+\varepsilon
$$

Panel A: Comparison of successive models

\begin{tabular}{|c|c|c|c|c|}
\hline & $\mathbf{N}$ & $\begin{array}{c}\text { Mean sum of } \\
\text { squares of residual }\end{array}$ & $\begin{array}{c}\text { Dispersion-test } \\
\text { (t-statistic) }\end{array}$ & $\begin{array}{l}\text { Vuong-test } \\
\text { (t-statistic) }\end{array}$ \\
\hline Model 1 & 93 & 716 & & \\
\hline Model 2 & 93 & 652 & $\begin{array}{l}-1.384 \\
(0.170)\end{array}$ & $\begin{array}{l}-1.508 \\
(0.135)\end{array}$ \\
\hline Model 3 & 93 & 698 & $\begin{array}{l}1.009 \\
(0.316)\end{array}$ & $\begin{array}{l}1.055 \\
(0.294)\end{array}$ \\
\hline Model 4 & 93 & 710 & $\begin{array}{l}0.443 \\
(0.658)\end{array}$ & $\begin{array}{l}0.454 \\
(0.651)\end{array}$ \\
\hline Model 5 & 93 & 710 & $\begin{array}{l}-0.016 \\
(0.988)\end{array}$ & $\begin{array}{l}-0.016 \\
(0.988)\end{array}$ \\
\hline Model 6 & 93 & 594 & $\begin{array}{r}*-1.716 \\
(0.090)\end{array}$ & $\begin{array}{r}*-1.882 \\
(0.063)\end{array}$ \\
\hline \multicolumn{5}{|c|}{ Panel B: Comparison of each model to the base model } \\
\hline & $\mathbf{N}$ & $\begin{array}{l}\text { Change in mean } \\
\text { sum of squares of } \\
\text { residual }\end{array}$ & $\begin{array}{c}\text { Dispersion-test } \\
\text { (t-statistic) }\end{array}$ & $\begin{array}{l}\text { Vuong-test } \\
\text { (t-statistic) }\end{array}$ \\
\hline Model 2 vs 1 & 93 & -64 & $\begin{array}{l}-1.384 \\
(0.170)\end{array}$ & $\begin{array}{l}-1.508 \\
(0.135)\end{array}$ \\
\hline Model 3 vs 1 & 93 & -18 & $\begin{array}{l}-0.691 \\
(0.491)\end{array}$ & $\begin{array}{l}-0.715 \\
(0.477)\end{array}$ \\
\hline Model 4 vs 1 & 93 & -6 & $\begin{array}{l}-1.012 \\
(0.314)\end{array}$ & $\begin{array}{l}-1.027 \\
(0.307)\end{array}$ \\
\hline Model 5 vs 1 & 93 & -6 & $\begin{array}{l}-0.687 \\
(0.494)\end{array}$ & $\begin{array}{l}-0.697 \\
(0.488)\end{array}$ \\
\hline Model 6 vs 1 & 93 & -122 & $\begin{array}{r}*-1.776 \\
(0.079)\end{array}$ & $\begin{array}{r}*-1.953 \\
(0.054)\end{array}$ \\
\hline
\end{tabular}

Model 1 Containing only the equity accounted carrying amounts and disclosed fair values of listed associates

Model 2 Containing only the disclosed net profit of the listed associates

Model 3 Containing only the disclosed revenue of the listed associates

Model 4 Containing only the disclosed total assets of the listed associates

Model 5 Containing only the disclosed total liabilities of the listed associates

Model 6 Containing all of the disclosed summarised financial information of the listed associates

The Dispersion-test assesses the significance of changes in the variance of the error term (c) using unstandardized residuals from each model in a paired sample ANOVA.

The Vuong-test (Vuong, 1989) is directional. Positive test statistics indicate that the first model is superior to the second model, while negative test statistics indicate that the second model is superior to the first model.

* Significant at the $10 \%$ level $\quad * *$ Significant at the $5 \%$ level $\quad * * *$ Significant at the $1 \%$ level (p-values for 2-tailed significance are indicated within the brackets) 